Thorolfur Gudnason MD, PhD Chief Epidemiologist Centre for Health Security and Communicable Disease Control / Directorate of Health.

https://doi.org/10.17992//bl.2017.11.157

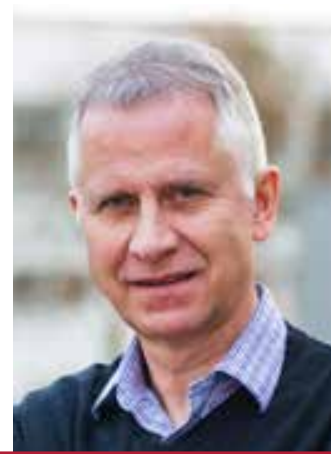

\section{Pórólfur Guðnason}

sóttvarnalæknir

Embætti landlæknis

\title{
Aukning á kynsjúkdómum á Íslandi - Hvað er til ráða? -
}

Alpjóðaheilbrigðisstofnunin (WHO) telur að um ein milljón einstaklinga í heiminum öllum fái kynsjúkdóm á hverjum degi og par af eru flestar sýkinganna einkennalausar eða einkennalitlar. Um 30 sýklar (bakteríur, veirur og sníkjudýr) geta smitast með kynmökum en flestar sýkingarnar eru af völdum sárasóttar, lekanda, klamydíu, lifrarbólgu B, HIV, HPV, herpes simplex og/ eða trichomonas. Af peim er talið að árlega greinist 131 milljón einstaklinga með klamydíu, 78 milljónir með lekanda, 5,6 milljónir með sárasótt og 143 milljónir með trichomonas.

Á Íslandi hafa heilbrigðisyfirvöld fylgst náið með faraldsfræði sárasóttar, lekanda, klamydíu, HIV og lifrarbólgu B í marga áratugi. Fylgst hefur verið með árlegum fjölda einstaklinga sem greinast með sárasótt og/eða lekanda frá 1896, klamydíu frá 1982, HIV frá 1983 og lifrarbólgu B frá 1985.

Á fyrri hluta 20. aldar var lekandi algengur á Íslandi og greindust flestir á árum seinni heimsstyrjaldarinnar, eða tæplega 600 tilfelli á hverja 100.000 íbúa á hverju ári. Á seinni hluta 20. aldar lækkaði nýgengið verulega og upp úr 1990 var fjöldinn kominn niður í um tvo einstaklinga á hverja 100.000 íbúa. Frá árinu 2004 hefur árlegur fjöldi hins vegar aukist og á árinu 2016 greindust 27 einstaklingar á hverja 100.000 íbúa, eða alls 89 manns. Í dag eru flestir sem greinast með lekanda karlmenn sem stunda kynlíf með öðrum karlmönnum.

Sama próun hefur átt sér stað með sárasótt. Á tímum seinni heimsstyrjaldarinnar greindust árlega um 110 einstaklingar með sárasótt á hverja 100.000 íbúa en með tilkomu penicillíns fækkaði peim í 1-5 á ári upp úr 1970. Frá 2013 hefur árlegur fjöldi nýgreindra einstaklinga með sárasótt hins vegar aukist umtalsvert og greindust 10 á hverja 100.000 íbúa (alls 33) á árinu 2016. Pessi próun hefur haldið áfram á árinu 2017 og stefnir í tvöfalt fleiri nýgreiningar á árinu miðað við 2016. Flestir peirra sem greinast í með sárasótt í dag eru karlmenn sem stunda kynlíf með öðrum karlmönnum.

Frá pví að fyrsti einstaklingurinn greindist með HIV hér á landi á árinu 1983 hafa 300 manns greinst með sjúkdóminn og 39 látist af völdum alnæmis (AIDS). Fjöldi nýgreindra hefur verið um 8-13 á ári en frá 2010 hefur fjöldinn aukist. Á árinu 2016 greindust 28 manns með HIV og höfðu ekki fleiri einstaklingar greinst á einu ári síðan faraldurinn hófst. Um priðjungur peirra sem greinast með HIV-sýkingu eru karlmenn sem stunda kynlíf með öðrum karlmönnum, priðjungur gagnkynhneigður og priðjungur sprautufíklar.

Um 2000 manns greinast hér á landi árlega með klamydíu. Pessi fjöldi hefur verið stöðugur á síðustu árum og er nýgengi klamydíu hérlendis með pví hæsta sem pekkist í Evrópu. Klamydía er algengust hjá ungmennum á aldrinum 15-25 ára.

Ástæður fyrir pessari aukningu á kynsjúkdómum hér á landi eru ekki alveg ljósar. Vafalaust er um marga samspilandi pætti að ræða eins og vaxandi kæruleysi í kynlífi, skort á notkun smokka, vaxandi fjölda dvalarleyfisumsækjenda og mikill fjöldi ferðalaga Íslendinga erlendis. Pessi próun á útbreiðslu kynsjúkdóma er ekki bundin við Ísland pví sama próun hefur sést bæði austan hafs og vestan.

Með vaxandi útbreiðslu kynsjúkdóma hér á landi má búast við að sjá alvarlegar afleiðingar pessara sjúkdóma sem ekki hafa sést hér um árabil. Má par fyrst nefna alvarlegar afleiðingar sárasóttar eins og meðfædda sýkingu og meðfæddar HIV-sýkingar. Pví eru læknar og aðrir heilbrigðisstarfmenn hvattir til að vera á varðbergi gagnvart pessum sjúkdómum í sínum daglegu störfum.

Mikilvægt er að menn taki höndum saman um að snúa pessari próun við. Heilbrigðisráðherra skipaði fyrr á árinu starfshóp undir forystu sóttvarnalæknis sem fékk pað verkefni að koma með tillögur að aðgerðum til að stemma stigu við útbreiðslu kynsjúkdóma og mun hópurinn væntanlega skila tillögum sínum á næstunni. Nauðsynlegt er að huga að mörgum páttum í pessari baráttu eins og betri og meiri upplýsingagjöf um faraldsfræði pessara sjúkdóma, bættu aðgengi að greiningarprófum, meiri og skipulagðari skimun hjá áhættuhópum, aukinni fræðslu í skólum og meðal almennings um áhættupætti pessara sjúkdóma, og innleiðingu á skaðaminnkandi aðgerðum. Sem dæmi um skaðaminnkandi aðgerðir má nefna nálaskiptaprógrömm hjá fíkniefnaneytendum og notkun smokka hjá áhættuhópum. Aðeins með víðtækum og samhentum aðgerðum mun okkur takast að bæta ástandið í pessum flokki sjúkdóma. 